\title{
DISAGGREGATING CUSTOMARY INTERNATIONAL LAW
}

\author{
PAUL B. STEPHAN* \\ INTRODUCTION
}

Bradley and Gulati's provocative paper presumes that customary international law ("CIL") contains a single exit issue. In response, they provide a set of new rules that would allow some exit under certain conditions. ${ }^{1}$ This Essay argues that, as a matter of current practice, CIL does not adhere to a single rule regarding exit. As a result, possibilities of exit are more abundant than many pundits claim. The Essay's larger goal is to complement and extend Bradley and Gulati's argument. Their proposal to liberalize and formalize exit from CIL does not represent as great a break from existing practice as their critics assert, and as they themselves sometimes imply.

The question of exit from CIL represents one instance of a larger problem in international law scholarship. Specialists, for reasons both ideological and institutional, have sought to construct a CIL that contains clear, relentless, and sweeping principles. They do this at the expense of a candid account of state practice and only by distancing themselves from the overarching principle of state consent. ${ }^{2}$ This Essay seeks to ground CIL more firmly in state interests and thus to resist the appropriation of CIL to serve other agendas. It demonstrates that CIL has more facets, complexities and variations than most contemporary scholars admit.

Tribunals, courts, and publicists alike talk about CIL as if it were a monolithic construct. This move allows international lawyers to assert that a set of uniform rules governs the making, application and unmaking of CIL. The monolithic move results not from a careful assessment of actual

* John C. Jeffries, Jr. Professor of Law and Elizabeth D. and Richard A. Merrill Professor of Law, University of Virginia. I am grateful to Curtis Bradley and Larry Helfer for organizing the Duke Workshop and to participants for their reaction to my presentation there. All errors and misjudgments reflect stubborn resistance to good advice.

1. See generally Curtis A. Bradley \& Mitu Gulati, Withdrawing from International Custom, 120 YALE L.J. 202 (2010).

2. Jorg Kammerhofer, Lawmaking by Scholarship? The Dark Side of $21^{\text {st }}$ Century Legal Methodology (Univ. Erlangen-Nuremberg Law Sch. working paper), available at http:// papers.ssrn.com/sol3/papers.cfm?abstract_id=1631510. 
state practice, but rather from a tendency toward abstraction and generality fueled largely by a concern about the underlying legitimacy of international law as such. ${ }^{3}$ But in a world where acceptance of the contribution of international law to social ordering is widespread and manifest, instrumental concerns replace existential anxiety. In this world, we need a more fine-grained analysis. By focusing on the work that CIL does, rather than defending its existence as part of a larger system of international law, there emerge various kinds of CIL with different norms of both creation and destruction.

My focus on a disaggregated CIL, i.e., what distinguishes the various practices that make up CIL, reflects a broader interest in subjecting international law to a positive and instrumental analysis, thus avoiding the normative approach that too often isolates the field from mainstream legal academic discourse. In earlier work, I demonstrated that international law, rather than operating as a global legal system applicable to all states, varies among states in ways that reflect the dynamics of international relations. ${ }^{4}$ Here, I take the first steps toward disaggregating CIL by function, rather than by state. By understanding the different kinds of work that CIL does, one can appreciate better the various exit options that accompany these functions.

CIL has many uses. First, it can provide a rule of decision for international tribunals or national courts to apply. Given the wide variety of tribunals and courts, one might expect that each would develop its own approach to CIL. An international tribunal might have an open-ended mandate, first to derive rules that promote dispute settlement, and then to attribute those rules to CIL. ${ }^{5}$ Alternatively, a tribunal might be saddled with

3. This tendency reflects an existential anxiety about the perennial issue of the nature of international law as law. The problem is similar to the recently expressed worries about the fragmentation of international law, which also reflect a concern that the essential legitimacy of international law might be in question. For articulation of this anxiety from a position of high authority within the international law hierarchy, see Rep. of the Int'l Law Comm'n, 58th Sess, May 1-June 9, July 3-Aug. 11, 2006, I 251, U.N. Doc. A/61/10, GAOR, 61st Sess., Supp. No. 10 (2006). For trenchant criticism of the authoritarian position, see Tomer Broude, Fragmentation(s) of International Law: On Normative Integration as Authority Allocation, in THE SHIFTING AllOCATION OF AUTHORITY IN INTERNATIONAL LAW: CONSIDERING SOVEREIGNTY, SUPREMACY AND SUBSIDIARITY 99 (Tomer Broude \& Yuval Shany eds., 2008). See also Eyal Benvenisti \& George W. Downs, The Empire's New Clothes: Political Economy and the Fragmentation of International Law, 60 STAN. L. REV. 595 (2007) (discussing political dimension of fragmentation in the course of critique).

4. Paul B. Stephan, Symmetry and Selectivity: What Happens in International Law When the World Changes, 10 CHI. J. INT'L L. 91 (2009).

5. See Eyal Benvenisti, Customary International Law as a Judicial Tool for Promoting Efficiency, in THE IMPACT OF INTERNATIONAL LAW ON INTERNATIONAL COOPERATION 85 (Eyal Benvenisti \& Moshe Hirsch eds., 2004). 
an extensive set of fully articulated rules to enforce, in which case it might invoke CIL to address only interstitial problems, such as treaty interpretation.

Second, a national court might use CIL as a substitute for constitutional rules, if that country's legal system does not generally recognize a judicial power of constitutional review. Alternatively, a domestic court might have well established common law powers, including a capacity to override domestic legislation, based on domestic rather than international sources of authority. Each body, one would predict, will derive CIL differently depending on its structural attributes and consequent requirements. ${ }^{6}$

Third, CIL can promote Weberian rationality in social relations by organizing the international work of specialized bureaucracies (most prominently the military, but also environmental, financial, and trade regulators, among many others). ${ }^{7}$ CIL can provide a common ground of discourse among the national bureaucracies as well as a means of rationalizing the internal operations and control of each bureaucracy. Moreover, to the extent domestic bureaucracies face accountability from political principals, CIL can operate as a bonding mechanism. ${ }^{8}$ Again, the tasks faced by such bureaucracies, as well as the specifics of their political accountability, are likely to vary widely, leading to different tasks for, and limitations on, CIL.

Finally, CIL can serve as a location of scholarly discourse. Academics have their own incentives based on distinct pathways to fame and fortune. While some academic commentary might be addressed to the development of CIL for reasons of public policy, it would be naive to ignore the need for recognition and approbation that affects the content of legal scholarship. Again, these incentives can, and in the view of some authoritative viewers do, generate a different body of CIL from that which might operate in the first three contexts.

In each category one can observe different rules of derivation and, necessarily, of termination of CIL. In each case states wishing to avoid a rule of CIL have more opportunities to do so than the publicists' consensus asserts. I consider these categories in order.

6. See Paul B. Stephan, Revisiting the Incorporation Debate: The Role of Domestic Political Structure, 31 VA. J. INT'L L. 417 (1991).

7. See Max Weber, Economy And Society 24-26 (Guenther Roth \& Claus Wittich eds., Ephraim Fischoff et al. trans., Bedminster Press 1968) (1922).

8. On the concept of bonding as a means of reducing agency costs, see generally Michael C. Jensen \& William H. Meckling, Theory of the Firm: Managerial Behavior, Agency Costs and Ownership Structure, 3 J. FIN. ECON. 305 (1976). 


\section{CIL AS A RULE OF DECISION FOR INTERNATIONAL TRIBUNALS}

Scholars often cite the decisions of international tribunals as evidence of the existence of CIL. But a fundamental feature of the international legal system - the independence of tribunals from each other and the consequent capacity of each of them to develop its own versions of CIL - promotes a form of exit in the form of rejections. While tribunals have not necessarily recognized a right of states expressly to exit from a rule of CIL, as Bradley and Gulati advocate, they certainly exercise that right themselves.

International tribunals do invoke CIL as a means of justifying their decisions. These bodies have limited jurisdiction, although the limits can vary widely, and have a wide range of structures. Consider first the two that feature most prominently in the scholarly literature. The International Court of Justice ("ICJ") can hear cases only where states consent to its jurisdiction, either ex ante through a treaty or ex post through a special agreement; it has a stable membership, based on a principle of national designation, and relatively long terms of office; and it has a mandate to apply a wide range of rules of law, not just treaties or CIL. ${ }^{9}$ In comparison, the International Criminal Court ("ICC") can hear only cases that meet certain treaty-based criteria, most importantly that the defendant be an individual rather than a public or private entity, but it alone has kompetenz kompetenz (that is, the authority to determine one's authority) to determine whether these criteria have been met. ${ }^{10}$ It also has stable membership based on national designation, and its statute contains a number of specific substantive rules that it must apply, including various defenses and exclusions from criminal liability. ${ }^{11}$

9. It is not uncommon for scholars and advocates to characterize Article 38 of the Statute of the ICJ as defining what constitutes international law. See, e.g., RESTATEMENT (THIRD) OF THE FOREIGN RELATIONS LAW OF THE UNITED STATES $\S 102$ rptr. note 1 (1987) ( describing Article 38 as "a provision commonly treated as an authoritative statement of the 'sources' of international law"). A more accurate account of that provision, however, is that it identifies the kinds of law that the ICJ may apply, without necessarily converting all of the applicable rules into international law.

10. Contrast this with the ICJ, where a reasonably good argument exists that the Security Council has ultimate kompetenz kompetenz. Cf. Questions of Interpretation and Application of the 1971 Montreal Convention Arising from the Aerial Incident at Lockerbie (Libya v. U.S.), 1998 I.C.J. 115, 162 (Schwebel, J., dissenting) (finding decisions of the Security Council bind the parties and thus the ICJ).

11. The provision in the ICC Statute equivalent to Article 38 of the ICJ Statute is Article 21, which authorizes the Court to apply treaties, "the principles and rules of international law, including the established principles of the international law of armed conflict," and general principles of law derived from national legal systems. Rome Statute of the International Criminal Court art. 21, July 7, 1998, 2187 U.N.T.S. 90. 
While the ICJ and the ICC attract much scholarly attention, perhaps because of their association with the United Nations ("UN") system, ${ }^{12}$ other tribunals do much more of the heavy lifting in the international dispute resolution system. The Dispute Settlement Body of the World Trade Organization ("WTO"), which combines ad hoc arbitration with appellate review exercised by a permanent body, hears all disputes involving the various Uruguay Round treaties. Its output dwarfs that of the ICJ and the ICC. Typically, Dispute Settlement Body opinions analyze and apply treaties, although they occasionally resort to CIL to derive rules of interpretation. Other tribunals mostly fall into two additional categories: regional courts such as the European Court of Justice and the European Court of Human Rights, and ad hoc arbitration of investment and commercial disputes. These tribunals are rooted in particular treaty regimes but, like the Dispute Settlement Body of the WTO, draw on CIL as needed. ${ }^{13}$

Each of these tribunals has occasion to discuss and apply CIL. While one cannot find any extended discussion by them of a state's power to exit from CIL, there exists ample evidence of the tribunals' power to achieve a kind of exit through means of interpretive independence. No mechanism (such as a supreme tribunal for all international tribunals) or widely embraced rule of recognition exists that could assign priority to the pronouncements on CIL emanating from these various tribunals. ${ }^{14}$ As H.L.A. Hart observed sixty years ago, international law lacks a rule of recognition that would compel independent actors to accept that CIL arising in one dominion applies throughout the system. ${ }^{15}$ No tribunal has any particular duty of deference to any other, and the ad hoc bodies have no special obligation to agree among themselves. Instead, international tribunals remain free to develop independent accounts of CIL that can contradict each other. And tribunals retain the power to change their mind, to distinguish their own precedents, and to ignore the claims of other tribunals. What we can observe is, if not quite a cacophony, widely

12. Although, one should note, the connection is somewhat attenuated. Of the five permanent members of the UN Security Council, only the United Kingdom accepts the compulsory jurisdiction of the ICJ, and no significant military power has joined the Rome Statute of the International Criminal Court.

13. For a review of international tribunals and their role in the production of international law, see Robert E. Scott \& Paul B. Stephan, The Limits of leviathan: Contract Theory and the ENFORCEMENT OF INTERNATIONAL LAW 128-41 (2006).

14. See Chester Brown, A Common Law of International Adjudication 4 (2007) (noting independence of tribunals regarding substantive principles of law but arguing for a convergence regarding their procedures).

15. H.L.A. HART, THE CONCEPT OF LAW 209 (1961). 
divergent views about the content of CIL. And the power to reject claims about CIL functions as a kind of exit option, even if not as explicit as Bradley and Gulati would like.

Evidence abounds of the power of tribunals to effect an exit from particular rules of CIL by simple rejection. First, and most importantly, tribunals can refuse to recognize claims about CIL that other bodies have made. Consider, for example, the question of the responsibility of a state for private armies operating under its supervision. The International Court of Justice determined, as a matter of CIL, that state responsibility existed only if a state had "effective control of the military or paramilitary operations" at issue. ${ }^{16}$ A decade later, the International Criminal Tribunal for Former Yugoslavia ("ICTY") relaxed this standard by imputing responsibility where a state had merely "overall control" of the group without exercising operational control of the group's actions. ${ }^{17}$ The ICTY, in other words, could exit from the ICJ's rule through the simple expedient of denying its status as CIL. The tribunal, of course, did not describe what it was doing as exiting, but that certainly was the result.

Complementing the power to deny the existence of a rule of CIL is the power to distinguish away rules that become unwelcome. Few if any international tribunals comprise only members with a strict common-law background, but most tribunals seek to provide reasoned decisions that give due regard to prior determinations. As a generalization, most tribunals have demonstrated a capacity to work around prior claims about CIL that they find inconvenient or confining. A striking recent instance is the ICJ's contributions to the CIL governing the continuity of treaty obligations when a state undergoes a fundamental change. In a 2004 decision, the ICJ determined that, due to the former Yugoslavia's loss of UN membership following its 1992 breakup, the country lacked the capacity to invoke ICJ jurisdiction to consider claims that other states had engaged in unlawful aggression against its territory and interests. ${ }^{18}$ A little more than two years later, the ICJ ruled that, during the same period, Yugoslavia remained bound by the obligations of the Genocide Convention and thus was required to submit to ICJ jurisdiction to consider claims that it had violated

16. Military and Paramilitary Activities in and Against Nicaragua (Nicar. v. U.S.), 1986 I.C.J. 14, ๆ 115 (June 27).

17. Prosecutor v. Tadic, Judgment, Case No. IT-94-1-A, ๆף 131-37 (Int'l Crim. Trib. For the Former Yugoslavia July 15, 1999).

18. See Legality of Use of Force (Serb. \& Mont. v. Belg.), 2004 I.C.J. 279, 327-328 (December 15). 
that treaty. ${ }^{19}$ In the first case, the tribunal assigned weight to the determinations of other bodies, especially the UN Security Council, regarding Yugoslavia's place in the UN treaty system after 1992. In the later case, it gave no weight to Yugoslavia's banishment from the UN. These cases illustrate the capacity of any international tribunal to effectively turn on a dime when a prior rule of CIL becomes inconvenient.

The status quo does not offer states a mechanism to declare explicitly, in advance of any disputes arising, what rules of CIL they would regard as inapplicable to themselves. Bradley and Gulati offer exactly this extension, a kind of safe harbor to states seeking exit from CIL, at least in situations where no countervailing reliance arguments apply. But such disclaimers remain open to interpretation once an actual dispute arises. ${ }^{20}$ On balance, it is not clear that the formal exit rule that Bradley and Gulati advocate would provide much greater comfort to recalcitrant states faced with an ambitious international tribunal.

\section{CIL AS A RULE OF DECISION FOR NATIONAL COURTS}

Consider next the CIL that national courts apply. U.S. practice is highly relevant and illustrative of how a national court may use CIL. For the most part, authority to apply CIL depends on the consent of the political branches, and exit can result simply from a withdrawal of consent or a substitution of a new rule by Congress and, in some cases, the Executive.

In instances where Congress has given a reasonably clear signal that it wants the judiciary to exercise lawmaking powers, the Supreme Court has embraced a liberal and inclusive approach to interpreting CIL. ${ }^{21}$ In most other cases, however, the modern Court has resisted open-ended invocations of CIL. The two leading decisions, Banco Nacional de Cubav. Sabbatino ${ }^{22}$ and Sosa v. Alvarez-Machain, ${ }^{23}$ concentrate on the problematic

19. Application of the Convention on the Prevention and Punishment of the Crime of Genocide (Bosn. \& Herz. v. Serb. \& Mont.), Judgment (Feb. 26, 2007), available at http://icjcij.org/docket/files/91/13685.pdf.

20. To consider an analogy, the United States by a valid treaty reservation had barred any jurisdiction of the ICJ over claims that it had violated the Geneva Conventions. In the Military and Paramilitary Activities case, the ICJ circumvented the reservation by determining that these Conventions had become CIL. Military and Paramilitary Activities, 1986 I.C.J. at 19 34-43. Surely a court capable of such interpretative legerdemain to protect its jurisdiction could do similar wonders to a prior disavowal of some particular rule of CIL.

21. See., e.g., Abbott v. Abbott, 560 U.S. 1 (2010) (regarding the international abduction of children); Hamdan v. Rumsfeld, 548 U.S. 557 (2006) (regarding the law of war); United States v. Louisiana, 363 U.S. 1 (1960) (regarding the boundary of territorial seas); In re Yamashita, 327 U.S. 1 (1946) (regarding the law of war).

22. 376 U.S. 398 (1964).

23. 542 U.S. $692(2004)$. 
aspects of judicial lawmaking. In the course of rejecting a rule of CIL governing expropriations of foreign investors, Sabbatino generally instructed the judiciary not to assume a leading role in establishing principles of international law. ${ }^{24}$ Sosa, in determining what constitutes a tort in violation of the law of nations, stated that "federal courts should not recognize private claims under federal common law for violations of any international law norm with less definite content and acceptance among civilized nations than the historical paradigms familiar when $\S 1350$ was enacted." ${ }^{25}$ Both decisions reflect two judgments. First, the Court believes that the specification of rules regulating primary conduct is principally the function of the legislature. Second, the Court takes for granted its capacity to invoke domestic constitutional norms to override legislative decisions that it finds especially objectionable. As a result, these decisions leave only a small role for the U.S. courts to determine whether CIL applies, much less whether a rule exists but has been avoided through exit.

Contrast the United States' approach with that of countries with weak legal institutions, which are often a result of sudden regime change. Not all such countries appeal to international law, including CIL, as an alternative source of legitimizing norms, but many do. Postwar Germany and Italy are early examples, followed by post-socialist Eastern Europe and post-apartheid South Africa. Commentators have noted that these countries largely have used international law as a means of solidifying liberal gains. ${ }^{26}$ What some of these commentators do not appear to appreciate, however, is that the choice of international law as a means to this end reflects not a heightened appreciation of the value and importance of international law so much as a realization that these countries' own domestic legal institutions provided an insufficient basis for legitimacy.

Because national courts interpret CIL with a range of interests and agendas, we should expect their determinations of what constitutes CIL to vary significantly. A casual survey suggests that this is true. In Europe, for example, the English House of Lords (now the Supreme Court) has refused to apply CIL that lacks widespread support, while the Italian Supreme Court on occasion has proposed new CIL rules. ${ }^{27}$ The CIL that Indian

24. 376 U.S. at 407-08.

25. 542 U.S. at 732.

26. See e.g., Ryan Goodman, Human Rights Treaties, Invalid Reservations, and State Consent, 96 AM. J. INT'L L. 531 (2002); Andrew Moravcsik, The Origins of Human Rights Regimes: Democratic Delegation in Postwar Europe, 54 INT'L ORG. 217 (2000).

27. Compare Ferrini v.Repubblica Federale di Germania, Corte di Cassazione Sezione Civile [Supreme Court Civil Section] Mar. 11, 2004, 87 Rivista Di DiRITTO InTERnAZIONALE 539 (2004) (It.), with Jones v. Saudi Arabia, [2006] UKHL 26 (appeals taken from Eng.). 
courts have incorporated into their domestic law is significantly different from the CIL in other jurisdictions, especially in other Commonwealth countries and the United States. ${ }^{28}$ The CIL that American courts will apply in Alien Tort Statute actions is circumscribed and likely to diminish further. $^{29}$

Consider another example, the CIL of foreign sovereign immunity in domestic courts. Early on the United States adopted a doctrine that seemed to give its courts control over the contours of this immunity. By the 1930s, however, the law had evolved into a matter of separation of powers, with the Executive holding the ultimate authority to decide which suits could proceed. By the mid-century the Executive had determined to change its practice and announced an intention to apply henceforth the restrictive theory of sovereign immunity. ${ }^{30}$ A quarter-century later, Congress displaced the Executive altogether by codifying the applicable rules, including a modified version of the restrictive theory. ${ }^{31}$ Later, it revised the statute in the face of new interests and concerns. In the first decade of the twenty-first century, some have looked to this U.S. practice and to various multilateral treaties as evidence of a new CIL embracing the restrictive theory. ${ }^{32}$

This sequence is noteworthy because the United States throughout regarded the nation's practice as both consistent with and contributing to CIL. The specific locus of domestic lawmaking-whether common law, statute, or treaty-was irrelevant to the broad international law question, even though the source was highly meaningful in defining the precise

28. See, e.g., Eyal Benvenisti, Reclaiming Democracy: The Strategic Uses of Foreign and International Law by National Courts, 102 AM. J. INT'L L. 241 (2008).

29. For example, one leading court has ruled that the Alien Tort Statute does not provide a basis for suits brought against corporations. Kiobel v. Royal Dutch Petroleum Co., 621 F.3d 111 (2d Cir. 2010). The plaintiffs have sought a rehearing. If the panel decision holds, it will not end this litigation but it will eliminate a class of defendants with significant resources and thus reduce the rewards to plaintiffs.

30. Letter from Jack B. Tate, Acting Legal Adviser, Dep't of State, to Acting Attorney Gen. Philip B. Perlman (May 19, 1952), reprinted in 26 Dep't State Bull. 984-85 (1952). "Under this theory, immunity is confined to suits involving the foreign sovereign's public acts, and does not extend to cases arising out of a foreign state's strictly commercial acts." Verlinden B.V. v. Cent. Bank of Nig., 461 U.S. 480, 487 (1983).

31. See Austria v. Altmann, 541 U.S. 677, 701 (2004):

The issue now before us, to which the Brief for United States as Amicus Curiae is addressed, concerns interpretation of the FSIA's reach - a "pure question of statutory construction . . . well within the province of the Judiciary." [citation omitted]. While the United States' views on such an issue are of considerable interest to the Court, they merit no special deference.

32. See Permanent Mission of India v. City of New York, 551 U.S. 193, 199, 201-02 (2007) (describing Foreign Soverign Immunities Act as codifying international law and then looking to The Vienna Convention on Diplomatic Relations to determine content of international law). 
content and scope of immunity. At no time did the United States exit from the abstract proposition that foreign sovereigns enjoy some kind of immunity. But the rules governing immunity changed over time, reflecting the concerns and capabilities of the relevant domestic decisionmaker.

A similar pattern can be seen in the United States' application of CIL through the Alien Torts Statute. A judicial process exists, involving a three-tiered hierarchy of courts, to apply the statute. Different courts have read different things in the law, with the Supreme Court's involvement limited so far to repudiating one determination-that the Alien Torts Statute extends to a supposed rule of CIL prohibiting arbitrary detentionby the Ninth Circuit. ${ }^{33}$ From the perspective of an external viewer, the United States first embraced a CIL principle forbidding such detention and then exited. From a domestic perspective, the competent legal decisionmakers played out their roles.

In sum, when exiting CIL domestic courts have all the options available to international tribunals, namely, the power to treat pronouncements by other authorities as proposals rather than commitments, and the capacity to distinguish and otherwise move away from earlier decisions on CIL. In addition, domestic courts can exit by deferring to domestic, nonjudicial official actors. The U.S. law of foreign sovereign immunity illustrates the mechanisms of deference: The rule that gave the Executive final say over immunity from the 1930s until adoption of the Foreign Sovereign Immunities Act, and the enactment of that statute as a means of displacing judicial decisionmaking, put courts in the position of applying rules that may displace what they previously believed to be CIL. ${ }^{34}$

The point about domestic rejection of judicially recognized CIL through acts by the political branches can be generalized. In most legal systems, a domestic court must give priority to a superseding legislative enactment over its earlier construction of CIL. ${ }^{35}$ In the United States, this rule is absolutely clear, as much as international law specialists may complain about it. ${ }^{36}$ Legislation that overrules domestic judicial

33. Sosa v. Alvarez-Machain, 542 U.S. 692, 737-38 (2004).

34. Contemporary U.S. foreign sovereign immunity law, for example, may be inconsistent with CIL. One could argue, for example, that CIL treats immunity as the norm and recognizes only limited exceptions. The exceptions in the Foreign Sovereign Immunities Act for expropriations and for acts of terrorism, see 28 U.S.C. $\S \S 1605(a)(3), 1605$ A (2006), have no counterparts in the rules governing immunity recognized by other countries.

35. The statement in text puts to one side issues such as the use of CIL to impose an unorthodox interpretation on a domestic statute, as well as the precise mechanisms by which some states enforce CIL as a source of superlegislative norms, such as by resort to a specialized constitutional court.

36. See Julian G. Ku, Treaties as Laws: A Defense of the Last-in-Time Rule for Treaties and Federal Statutes, 80 IND. L.J. 319, 345-46 (2005). 
determinations of CIL would not obviate any claims that international tribunals, bureaucracies, or scholars might have about the ongoing international obligation, but it would require the domestic courts to stop recognizing the rule in question. At least in countries where powerful independent courts play a significant role in the development of legal policy - e.g., the United States - a mechanism that produces judicial exit is almost as important as one that leads to complete withdrawal from the particular norm. The power to apply a rule of CIL in civil litigation greatly adds to that rule's significance, and withdrawal of that power correspondingly diminishes it.

\section{CIL AS A SOURCE OF RULES FOR BUREAUCRACIES}

As noted above, CIL does more than provide dispute resolution bodies with a source of law. Much of CIL addresses specialized national bureaucracies, most prominently the armed forces. For these actors, CIL provides both a foundation for interactions with their peers in other nations and a set of rules for organizing bureaucracies' activities. The latter function is especially important to the extent that a bureaucracy faces different incentives from those facing the actors to whom the bureaucracy is accountable (presumably a nation's political leadership). As a bonding constraint on the political leadership-bureaucracy relationship, CIL limits both what the bureaucracy can do and what the political leadership can ask the bureaucracy to do.

Perhaps the best example of a type of CIL that addresses a specialized bureaucracy is the law of war. While many treaties address this subject, they often frame propositions at such a high level of abstraction that a CIL overlay is required to give the rule any meaning. Issues such as disproportionate use of force and excessive risk to noncombatants, for example, demand exposition to be operational. National militaries, which are without exception organized as bureaucracies, develop detailed glosses on treaties and extend CIL governing their operations in other directions. The manuals military bureaucracies publish provide a particularly rich source of information about the areas of consensus and disagreement among the bureaucracies. The militaries then organize training and discipline around these rules, thereby fairly effectively converting their version of CIL into a mechanism to develop internal control and command.

An effective body of rules that is internalized by a bureaucracy does more than facilitate a coherent hierarchy within the bureaucracy. It also clarifies the relationship between the bureaucracy and its political masters. The CIL of international humanitarian law, for example, gives political authorities both heightened assurance against renegade actions and, to 
some extent, constrains what these authorities can demand of their militaries. The conflict between career military lawyers and political appointees over detention policy during the Bush administration suggests how this bonding mechanism works, even as it highlights its limitations. ${ }^{37}$

This pattern extends to other subject areas where specialized bureaucracies confront international issues. Obvious examples include arms control, environmental regulation, resource management, the law of the sea, and police assistance (principally INTERPOL). Although they do not get as much attention in law journals as do military operations, all of these bureaucracies share the same structural characteristics: a small or nonexistent role for formal dispute resolution; highly technical fields that place a premium on specialized expertise; and frequent interactions among specialists across national borders.

Specialized technical subjects aside, bureaucratic CIL also undergirds the work of international law generalists, particularly those who work in foreign ministries. These lawyers focus largely on problems of treaty interpretation and on relations with international organizations (the United Nations in particular). Through ongoing exchanges, they identify areas of consensus on issues, such as the legal significance of particular terminology employed in UN Security Council Resolutions, the scope and effectiveness of treaties, and rules of state succession to treaty obligations.

Several overarching principles of CIL unify these areas-pacta sunt servanda (the obligation to honor an agreement) comes to mind-but these principles operate at a level of abstraction so great as to make them unhelpful to specialists operating in the field. More work (in the sense of organizing and constraining state behavior) is done in distinct and separate areas of consensus achieved by repeat interactions, punctuated with sharp disputes both over the content of the rules and the methodology for determining them. A current controversy illustrates the point. Recently, a pair of European law professors working on behalf of the International Committee of the Red Cross ("ICRC") published an extensive account of the CIL of jus in bello (the law governing conduct within an armed conflict). Representatives of the United States, the only superpower with extensive military operations outside its borders, issued a sharp rebuke, not just to the specific claims but also to the sources that the professors invoked to ground their assertions. ${ }^{38}$

37. See Deborah N. Pearlstein, Finding Effective Constraints on Executive Power: Interrogation, Detention and Torture, 81 IND. L.J. 1255 (2006).

38. Compare JeAn-Marie Henckaerts \& Louise Doswald-Beck, Customary INTERNATIONAL HUMANITARIAN LAW (2005), with Letter from John Bellinger III, Legal Adviser, U.S. Dep't of State, and Jim Haynes II, Gen. Counsel, U.S. Dep't of Def., to Dr. Jakob Kellenberger, 
Although this exchange might be viewed as a conflict in which only one side is in the right, a better perspective views it as a dialectical process that puts interest, reputation, and power into play. To the extent that the United States depends on cooperation with European militaries, the ICRC claims, which reflect the perspective of European states that have largely relinquished military power as an instrument of foreign policy, are likely to gain traction. To the extent that interactions with the considerably more bellicose Chinese and Russian military bureaucracies occupy the United States, and that European military influence further withers, the ICRC must revise its stance or it will find itself marginalized. New standards governing military behavior may emerge from the conflict, but logical rigor and normative aspirations are not likely to do much of the work of determining the new CIL.

There is no evidence that the standards that bureaucratic interaction generates are subject to the one-way ratchet that the no-exit approach to CIL supposes. Rather, bureaucracies adjust their consensus assumptions to circumstances. Rules ebb and flow in response to the problems that arise. What we know about the evolution of custom in other areas-the importance of norm entrepreneurs, the presence of network effects, the discipline of tit-for-tat interactions-seems to apply here as well. ${ }^{39}$

\section{CIL AS A SOURCE OF AUTHORITY AND A PLACE OF COMBAT IN SCHOLARLY DISCOURSE}

Finally, one must consider the invocation of CIL in the academy. Not so long ago in the United States, international law scholarship was largely marginalized and hermetic, mostly unconnected to high profile policy debates. Over the last twenty years, however, greater international economic activity, the threat of terrorism, and the emergence of human rights litigation have brought international law into prominence. As the significance of international law scholarship to the larger legal realm has grown, many scholars have been unable to resist the temptation to use law reviews as a forum for advocacy.

Judges have been wary of at least the more ambitious claims advanced by scholars. One leading U.S. court, confronted with the

President, Int'l Comm. of the Red Cross (Nov. 3, 2006), reprinted as John B. Bellinger III \& William J. Haynes II, A U.S. Government Response to the International Committee of the Red Cross Study on Customary International Humanitarian Law, 89 INT'L REV. RED CROSS 443 (2007), available at http://www.state.gov/s/1/2006/98860.htm, and W. Hays Parks, The ICRC Customary Law Study: A Preliminary Assessment, 99 AM. SOC'Y INT'L L. PROC. 208 (2005).

39. See SCOTT \& STEPHAN, supra note 13 , at 84-97. 
argument that scholarly authority should prevail in the determination of what rules of CIL a court may apply, responded sharply:

This notion-that professors of international law enjoy a special competence to prescribe the nature of customary international law wholly unmoored from legitimating territorial or national responsibilities, the interests and practices of States, or (in countries such as ours) the processes of democratic consent - may not be unique, but it is certainly without merit.

Put simply, and despite protestations to the contrary by some scholars (or "publicists" or "jurists"), a statement by the most highly qualified scholars that international law is $x$ cannot trump evidence that the treaty practice or customary practices of States is otherwise, much less trump a statute or constitutional provision of the United States at variance with $x$. This is only to emphasize the point that scholars do not make law, and that it would be profoundly inconsistent with the law-making processes within and between States for courts to permit scholars to do so by relying upon their statements, standing alone, as sources of international law. In a system governed by the rule of law, no private person- or group of men and women such as comprise the body of international law scholars-creates the law....

This admonition, however, has not robbed academic assertions of all influence. Official lawmakers still bolster their judgments with citations to academic support, even if such support is neither necessary nor sufficient to justify their decisions. While scholars may pursue controversies for their own instrumental ends-recognition, promotion, and patronage in particular-these efforts on occasion do end up bolstering, if not necessarily producing, concrete legal outcomes. ${ }^{41}$

This juxtaposition of scholars, courts, and legislatures illustrates a paradox. On the one hand, as Bradley and Gulati recount, strong support for the no-exit approach to CIL-one is tempted to say the only support that exists for the no-exit rule - can be found in scholarly commentary. On the other hand, scholars disagree profoundly about the content and function of CIL, some going so far as to question the legitimacy of CIL as a source

40. United States v. Yousef, 327 F.3d 56, 102 (2d Cir. 2003) (citation omitted).

41. An example of great success in this endeavor is Steven R. Ratner, Corporations and Human Rights: A Theory of Legal Responsibility, 111 YALE L. J. 443 (2001), which proposed the creation of a CIL of corporate responsibility for human rights violations. At least one court accepted the article as evidence of an established rule and quoted its evidence largely verbatim, including its mistakes. Presbyterian Church of Sudan v. Talisman Energy, Inc., 244 F. Supp. 2d 289, 316-17 (S.D.N.Y. 2003) (listing treaties cited by Ratner as evidence of rule, included miscited treaty incorrectly attributed to the United States). But see Kiobel v. Royal Petroleum Co., 621 F.3d 111 (2d Cir. 2010). 
of rules of decision in legal disputes. ${ }^{42}$ Whatever the authority of states to exit from CIL, it appears that scholars exercise this prerogative frequently and enthusiastically!

The significance of Bradley and Gulati's article derives from its launching of a new stream of scholarly argument about CIL. By challenging the claim that CIL does not contain an exit option, they create the possibility that it does. They have broached the subject in a respectable journal, bolstered by credible arguments marshaled with intelligence and technical skill, and thus have opened the path to influence outside the community of international law academics. With the publication of their article, Bradley and Gulati have shown that the authoritarian argument that all specialists agree that states may not unilaterally withdraw from any norm of CIL is false.

\section{CONCLUSION}

Thinking of CIL as a seamless whole ignores the fundamental differences among the various actors that contribute to its creation. Most importantly, this conception of CIL confuses actors who face real institutional constraints and some degree of accountability with those who do not. Most significantly of all, this conception of CIL omits something important about the way courts, tribunals, officials, and academics invoke, interpret, and comply with CIL: Their behavior is far more complex and pragmatic that then monolithic vision of CIL recognizes. The exit issue raised by Bradley and Gulati is only one instance where that the monolithic conception of CIL not only confuses but misleads.

A functional approach, which looks at the way particular actors invoke and debate CIL-in terms of the objectives, incentives, and constraints facing those actors - avoids this problem. What one loses in simplicity and elegance one gains in realism, depth, and color. This approach makes it possible to discover the work that CIL does, rather than pining for outcomes that remain beyond international law's grasp.

42. See, e.g., Jack L. Goldsmith \& Eric A. Posner, The Limits of International Law (2005). 